\title{
A Review of Promising Electrocoagulation Technology for the Treatment of Wastewater
}

\author{
Mervat A. Sadik \\ October High Institute for Engineering \& Technology, Giza, Egypt \\ Email: sadikmervat@yahoo.com
}

How to cite this paper: Sadik, M.A. (2019) A Review of Promising Electrocoagulation Technology for the Treatment of Wastewater. Advances in Chemical Engineering and Science, 9, 109-126. https://doi.org/10.4236/aces.2019.91009

Received: November 5, 2018

Accepted: January 27, 2019

Published: January 30, 2019

Copyright (c) 2019 by author(s) and Scientific Research Publishing Inc. This work is licensed under the Creative Commons Attribution International License (CC BY 4.0).

http://creativecommons.org/licenses/by/4.0/

(c) (i) Open Access

\begin{abstract}
A review of the literature published on topics interrelated to electrochemical treatment within wastewater by using sacrificial anodes was presented. Electrocoagulation (EC) is a technique used for water and has a great ability on various wastewater treatments, industrial processed water, and medical treatment. It has potential in removing various pollutants such as chemical oxygen demand turbidity, ammonia, color, and suspended solid. One of the most necessities industries is Textile industries which release large volumes of wastewater that contains different dyes. Azo dyes contain strong $\mathrm{N}=\mathrm{N}$ bond which is not easily broken by conventional methods. The discharge of this type of wastewater to natural watercourse can pose serious environmental impacts to aquatic life. Electrocoagulation (EC) method depends on several factors as electrode material, current density, operation time and PH. The review describes, discusses and compares the types of that electrode influencing the EC process in various wastewater and leachate. Both operating costs and electrical energy consumption values were found to vary greatly depending on the type of electrodes material and solution being treated.
\end{abstract}

\section{Keywords}

Wastewater Treatment, Electrochemical Treatment, Electrocoagulation, Sacrificial Anodes

\section{Introduction}

There are two main significances of wastewater treatment, one is defending the environment and the other one is sustaining fresh water resources. With the ever increasing standard of drinking water supply and the stringent environmental regulations regarding the wastewater discharge, electrochemical technologies have retrieved their importance worldwide during the past two decades. Elec- 
trocoagulation-electro flotation (ECF) technology is a treatment process of applying electrical current to treatment and flocculating contaminants devoid of having to add coagulations. Electrocoagulation has olden times as a water treatment technology having been working to remove a varied of pollutants. The textile industry wastewater varies extensively in terms of composition due to the regular impurity in fibers and the chemicals used in different processes. Various types of dyes are produced worldwide and are used in various industries; the author indicated in Table 1 some examples in recent applications of Electrocoagulation in treatment of water and wastewater, such as textile, cosmetic,

Table 1. Examples in recent Applications of Electrocoagulation in Treatment of Water and Wastewater.

\begin{tabular}{|c|c|c|c|}
\hline Reference & Type of wastewater & Anode-cathode & Removal efficiency \\
\hline Warren, R et al. (2018) & Metals & $\mathrm{Fe}-\mathrm{Fe}$ & $\mathrm{Fe}(99.17 \%), \mathrm{Mn}(99.97 \%)$ \\
\hline Naraghi et al. (2018) & Reactive dyes & $\mathrm{Fe}-\mathrm{Fe}$ & $96 \%$ (Color) \\
\hline $\begin{array}{l}\text { P. Mahammedrafi, et al. } \\
\text { (2018) }\end{array}$ & Fluoride ions & $\mathrm{Fe}-\mathrm{Fe}$ & $91 \%$ fluoride ions \\
\hline Francisco, P et al. (2017) & Whey acids & $\begin{array}{c}\text { Al-Fe, graphite and } \\
\mathrm{Ti} / \mathrm{RuO} 2\end{array}$ & $79 \%-49 \%$ contaminants \\
\hline LiR et al. (2017) & Landfill Leachate & $\mathrm{Al}-\mathrm{Al}$ & $99 \%-91 \%$ \\
\hline Bejjany, B et al. (2017) & Internal loop airlift & $\mathrm{Al}-\mathrm{Al}$ & $\begin{array}{l}70 \%-87 \% \text { energy } \\
\text { consumption }\end{array}$ \\
\hline Hariraj, S. et al. (2017) & $\begin{array}{l}\text { Removal of suspended } \\
\text { solids and metals from } \\
\text { synthetic water }\end{array}$ & $\mathrm{Al}-\mathrm{Al}$ & $\begin{array}{c}76.6 \% \text {, and reduced rates of } \\
99 \%, 59.2 \% \text {, and } 82.1 \% \text {, for } \\
\mathrm{Cu}, \mathrm{Cr} \text {, and } \mathrm{Zn}\end{array}$ \\
\hline Shobhan, M. et al. (2017) & Textile mill & $(\mathrm{SS}-\mathrm{Ti})-(\mathrm{Al}-\mathrm{Ti})$ & $90 \%-78 \%$ (Color) \\
\hline Seyed Ali et al. (2017) & Remazol Black B Dye & $\mathrm{Al}-\mathrm{Al}, \mathrm{Fe}-\mathrm{Fe}$ & $99 \%-91 \%$ (Color) \\
\hline Maghanga, J. et al. (2017) & Reactive Black 5 & SS-SS & 99.4\% (Color) \\
\hline Jorge, V et al. (2017) & $\begin{array}{c}\text { Palm Oil Mill, Paint } \\
\text { Wastewater }\end{array}$ & $\mathrm{Fe}-\mathrm{Fe}$ & $\begin{array}{c}65 \% \text { and } 76 \% \text { Total } \\
\text { Suspended and Dissolved } \\
\text { Solids }\end{array}$ \\
\hline $\begin{array}{l}\text { Alimohammadi, M et al. } \\
\text { (2017) }\end{array}$ & Natural organic matter & $\mathrm{Al}-\mathrm{Al}, \mathrm{Fe}-\mathrm{Fe}$ & 100\% (Color) \\
\hline Abubaker T et al. (2017) & Tannery & $\begin{array}{c}\text { aluminum } \\
\text { nanoparticles }\end{array}$ & $\begin{array}{c}\text { 98.98\%, } 90.6 \%, 70.40 \% \\
\text { 99.9\% and } 88.3 \% \text { of } \\
\text { Turbidity, COD, TDS, } \\
\text { Chromium and Sulphide }\end{array}$ \\
\hline Joseph, T. et al. (2017) & Abattoir & $\mathrm{Fe}-\mathrm{Fe}$ & 93\% (Color) \\
\hline Nasser, G .et al. (2017) & $\begin{array}{l}\text { Herbicide oxyfluorfen, } \\
\text { COD }\end{array}$ & $\begin{array}{c}\text { Fe-Fe., S.S-S.S, } \\
\text { Fe-Fe }\end{array}$ & $\begin{array}{c}(98.5 \%-90 \%, 99.2 \%-85 \% \\
96.1 \%-70.5 \% \text { (Color, } \\
\text { COD) }\end{array}$ \\
\hline Manoel É et al. (2016) & Dye yellow Sirius & $\mathrm{Al}-\mathrm{Al}$ & 95\% (Color) \\
\hline Murat Eyvaz (2016) & Brewing industry & $\mathrm{Al}-\mathrm{Al}, \mathrm{Fe}-\mathrm{Fe}$ & \\
\hline Vidal, J et al. (2016) & Acid Black 194 & $\mathrm{Fe}-\mathrm{Fe}$ & $100 \%$ (Color) \\
\hline Anmoldeep, S et al. (2016) & $\begin{array}{l}\text { Brilliant Green, Bromo } \\
\text { blue and Brilliant blue }\end{array}$ & $\mathrm{Fe}-\mathrm{Fe}$ & 100\% (Color) \\
\hline
\end{tabular}


paper, leather, pharmaceutical and food industry [1] [2] and [3]. Lately, electrocoagulation (EC) has been playing noticeable role in the drinking water treatment because it affords some substantial advantages such as quite compact, easy operation, automation, no chemical additives, and reduced amount of slug. Wastewater was considered for COD, Biochemical Oxygen Demand (BOD), pH, conductivity, chlorides, turbidity and color [4], and also in medical waste water [5] [6]. The effect of operating parameters such as current density, electrolysis time, and initial COD concentration was studied. Besides, energy and electrode consumption were examined. Electrocoagulation involves electrodes that are arranged in pairs-anodes and cathodes, whereby anodes (aluminum or iron electrodes) corrode to release active coagulants into solution. These hydroxides/polyhydroxides/polyhydroxy-metallic compounds have a strong affinity treatment of wastewater. Electrocoagulation technology is an alternative method to classic chemical coagulation that involves the use of alum (aluminum sulfate), ferric chloride $\left(\mathrm{FeCl}_{3}\right)$, or ferrous chloride. $\mathrm{EC}$ is talented of reducing chemicals by reason of the fact that the electrodes afford the coagulant in situ. However, sulfate $\left(\mathrm{Fe}_{2} \mathrm{SO}_{4}\right)$ can be very costly depending on the volume of water treated. The coagulant performed a similar function as the electrodes, neutralizing the charge of the particulates, thus allowed them to collect and settle at the bottom of the tank. In addition, electrocoagulation-flotation is talented of reducing waste production, time and electrical energy consumption for wastewater [7] [8] [9] while [10] and [11] enhanced electrocoagulation device for treating various types of industrial wastewater and observed how electrocoagulation-flotation(ECF) reactor can be effective, according to wastewater type, $\mathrm{pH}$, current density and type of metal electrodes (aluminum, steel). Among all the various technologies available, electrolysis is one of the best. The EC offers a substitute to use metal salt or polymer or polyelectrolyte addition so as to destabilize emulsion and suspension. The EC technology has been employed to remove metal, colloidal solid, particle, and soluble inorganic pollutant from the water/wastewater by applying highly charged polymeric metal hydroxide species. These species neutralize the electrostatic charge on suspended solids to facilitate accumulation or coagulation and the resultant separation from aqueous medium.

\section{Electrocoagulation Process}

The (EC) technology includes coagulation and precipitation of contaminants by a direct current electrolytic process followed by the separation of flocculent (settling or flotation) with or without the addition of coagulation-inducing chemicals. The water is pumped through a unit which consists of pairs of metal sheets called electrodes that are arranged. A direct current electric field is applied to the electrodes to induce the electrochemical reactions needed to achieve the coagulation. Coagulation technology induces Coagulation and precipitation of contaminants. In an EC process the coagulated ions a produced in "in situ" and it in- 
volves three successive stages.

1) Information of coagulants by electrolytic oxidation of the sacrificial electrodes.

2) Destabilization of the contaminants, particulates suspension and breaking of emulsions.

3) Aggregation of the destabilized phase to form flocculent.

Electrodes which produce coagulants into water are made from either iron or aluminium. Iron and aluminium cations dissolve from the anodes according to Equation (1) and Equation (2).

$$
\begin{aligned}
& \mathrm{Fe}(\mathrm{s}) \rightarrow \mathrm{Fe}^{\mathrm{n}+}(\mathrm{aq})+\mathrm{ne}^{-} \\
& \mathrm{Al}(\mathrm{s}) \rightarrow \mathrm{Al}^{3+}(\mathrm{aq})+3 \mathrm{e}^{-}
\end{aligned}
$$

And at cathode according to Equation (3)

$$
2 \mathrm{H}_{2} \mathrm{O}+2 \mathrm{e} \rightarrow \mathrm{H}_{2}+2 \mathrm{OH}^{-}
$$

In solution the positively charged ions are attracted with the negatively charged hydroxides to produce ionic hydroxides that have a strong attraction towards dispersed particles as well as counter ions to cause coagulation [12].

\section{Overview of Different Types of Water and Wastewater Recently Treated by Electrocoagulation-Electro Flotation (ECF) Technology}

The EC process is the electrochemical generation of metal ions (such as $\mathrm{Al}$ and $\mathrm{Fe}$ ) that act as destabilizing agents and leads to neutralization of electric charge for removing pollutants. This process has been proven to be very effective in removing contaminants from waters and is characterized by reduced sludge production, no requirement of chemicals, and ease of operation and electrical energy consumption. [13] demonstrated removal efficiency $91 \%$ of fluoride ions from water by Electrocoagulation process and maximum hardness removal $60 \%$ - 70\%, while [14] studied effluents from different industrial sectors. Using iron anode, $\mathrm{Fe}$ (99.17\%), Mn (99.97\%), TSS (99.35\%) and other metals such as $\mathrm{Cu}, \mathrm{Zn}$ and $\mathrm{Cd}$ were removed in more than $99 \%$, while the removal of $\mathrm{Pb}$ was very varied. The effluent from the treatment ponds of the waste disposal plant was processed using iron anodes, reaching a removal of $45.14 \%$ COD, with an energy consumption of $3.30 \mathrm{kwh} / \mathrm{m}^{3}$ at a cost of $0.29 \$ / \mathrm{m}^{3}$. [15] studied the textile wastewater contain Reactive Black 5 (RB5) as an Azo dye that causes serious damage to the environment and aquatic life in receiving water resources. The findings of this study demonstrated that the highest simultaneous removal performance (96\%). With the increasing of reaction time, the energy consumption, electrodes wear, $\mathrm{pH}$, final temperature of effluent, and removal efficiency would increase. Adsorption process could play a small role in the removal of the dye, while it was very effective in improving the performance of the electrocoagulation process. [16] observed few conventional and biological methods are inadequate and insufficient for the treatment of wastewater from dye industries. Ad- 
vance treatment processes such as electrocoagulation and Fenton oxidation process or combination of these processes can be a better option for treatment of such wastewater. This paper reviews the application of electrocoagulation and Fenton oxidation processes for the treatment of dye wastewater. Both electrode materials exposed similar pollutant removal performances while $\mathrm{Al}$ electrode was found cost effective one. [17] renewed electrocoagulation (EC) water-treatment processes. The outcome indicates that a maximum TSS removal efficiency of $76.6 \%$ and reduced rates of $99 \%, 59.2 \%$, and $82.1 \%$, for $\mathrm{Cu}, \mathrm{Cr}$, and $\mathrm{Zn}$, respectively. Moreover, kinetic study has also demonstrated that pollutants removal follows first-and second-order model with current density and EC time being dependent. [18] focused on, the performance of an EC process by incorporating titanium plates (Electro-oxidation) for the treatment of textile mill wastewater using Stainless Steel-Titanium (SS-Ti) and Aluminium-Titanium (Al-Ti). The COD removal efficiency of SS coated with sodium alginate hydrogel in combination with $\mathrm{Ti}$ was found to be $90 \%$ and $87 \%$ respectively. The power consumption of SS and Al was found to be $9.6 \mathrm{kWh} / \mathrm{m}^{3}$ and $5.25 \mathrm{kWh} / \mathrm{m}^{3}$. [19] carried out a study with wastewater from industrial pulp and paper recycling using electrocoagulation. Aluminum ( $\mathrm{Al})$ and Iron $(\mathrm{Fe})$ electrodes were used as the electrochemical cell set up, COD and color removal efficiency with the Fe electrode were $92 \%$ and $100 \%$, respectively. Al electrodes had lower efficacy for COD and color removal than the Fe electrode. [20] achieved a 94\% chemical oxygen demand (COD), $87 \%$ arsenic, $96 \%$ iron, and $86 \%$ phosphorus removal from landfill leachate. Besides electrical current, reaction time and $\mathrm{pH}$ are played a very important role in arsenic and phosphorus removal by electrocoagulation process. [21] reviewed and summarized that the recent development of arsenic removal in EC process including the effects of primary operating parameters, optimization of the EC performance, as well as the evaluation of EC reactor configurations. Production and characterization of EC products with respect to different electrodes are systematically discussed. Besides, this review will contribute to deepening the understanding of EC process for arsenic removal and offer useful information to researchers in this field. [22] carried out a study with surface water by an electrocoagulation-electroflotation process in internal loop Airlift reactor. The electrocoagulation-electroflotation kinetics is rapid and it increases with the increase of the initial electrical conductivity of the solution $\sigma 0$. To achieve a turbidity abatement of $40 \%$, and a reduction of $70 \%$ and $87 \%$. As for energy consumption, time, [23] obtained decolourization efficiency of the azo dye Reactive Black 5 (RB-5) from synthetic wastewater 99.4\% with Electrical energy consumption $0.75 \mathrm{kWh} / \mathrm{m}$. by using Electrocoagulation (EC) technique. [24] evaluated efficiency almost $100 \%$ of electrocoagulation (EC) for the removal of natural organic matter (NOM) by using iron ( $\mathrm{Fe}$ ) and aluminum ( $\mathrm{Al}$ ) electrodes. Electrical energy consumptions were $14.90 \mathrm{kWh} / \mathrm{kg} \mathrm{Al}$ (or $0.092 \mathrm{kWh} / \mathrm{m}^{3}$ ) and $2.88 \mathrm{kWh} / \mathrm{kg} \mathrm{Fe}$ (or $0.11 \mathrm{kWh} / \mathrm{m}^{3}$ ). Specific electrode consumptions were obtained to be 0.0062 and $0.0382 \mathrm{~kg} / \mathrm{m}^{3}$, and operating costs of the EC system 
were preliminary estimated at 0.057 and $0.119 \$ / \mathrm{m}^{3}$ for $\mathrm{Al}$ and Fe electrodes, respectively. [25] employed electrocoagulation technique for treating various wastewaters. Palm Oil Mill Effluent (POME) and Paint Wastewater (PW) using iron electrodes. Results revealed that this process could reduce the concentration of Total Suspended and Dissolved Solids (TSDP), in both POME and PW. The highest removal efficiencies of $65 \%$ and $76 \%$ were obtained for POME and PW, respectively. [26] successfully removed 99\%, 91\% of (Remazol Black B) colored water using electrocoagulation process is equipped with iron and aluminum electrodes, respectively. [27] treated tannery wastewater sample using an electrode of aluminum nanoparticles. The investigation of the tannery waste water showed high signs of pollution to remove $98.98 \%, 90.6 \%, 70.40 \%, 99.9 \%$ and $88.3 \%$ of Turbidity, COD, TDS, Chromium and Sulphide respectively. was carried out a study to investigate Reactive Red 76 (RR) and C.I. Disperse Blue 79 (DB). The process parameters investigated was found optimum efficient for of both dyes removal due to formation of Fe (III) as a coagulant in situ. [28] showed that EC technique is effective in abattoir wastewater treatment using Fe-Feelectrodes. The removal efficiency of $93.69 \%$, and $0.55 \mathrm{kWh} / \mathrm{L}$ power consumption. [29] used the electrocoagulation process to remove of the herbicide oxyfluorfen and chemical oxygen demand (COD) in aqueous solution. The results showed that the maximum removal efficiency for oxyfluorfen and COD were (98.5\% and $90 \%),(99.2 \%$ and $85 \%)$ and $(96.1 \%$ and $70.5 \%)$ by using iron $(\mathrm{Fe})$, stainless steel (S.S) and aluminum ( $\mathrm{Al}$ ) The energy consumption in the electrocoagulation process at optimum conditions $\left(15.9,16.65\right.$ and $\left.14.1 \mathrm{KWh} / \mathrm{m}^{3}\right)$ using $\mathrm{Fe}$, SS and $\mathrm{Al}$ electrodes respectively. [30] conducted the efficient removal of fluoride from the drinking water. Electrocoagulation technology provides some significant advantages such as quite compact, easy operation, automation, no chemical additives, high velocities and reduced amount of sludge. [31] investigated electrocoagulation process on the treatment of brewing industry effluents. The process operated with electrocoagulation reactor including four plate electrodes. Two electrode materials, $\mathrm{Fe}$ and $\mathrm{Al}$, were separately employed in parallel connection. [32] used electrocoagulation process (EC) for the elimination of Acid Black 194 textile dye from synthetic and textile wastewater (effluent) contaminated with Acid Black 194 dye, was carried out using aluminum anodes. The final result was absolutely decolourization with pure water have not dye and organic matter. [33] responded high removal efficiency of Brilliant Green, Bromo blue and Brilliant blue from aqueous using electrocoagulation methodology to determine the optimum conditions for the efficiencydye removal from solution [34] investigated, high efficiency more than $95 \%$ of decolourization from solutions containing dye yellow Sirius K-CF in aqueous media by applying aluminum electrode in electrocoagulation cell. [35] treated the real textile wastewater taken from dying process of the industry by electrocoagulation (EC) process. The results showed that MP-P mode was the most cost effective for both electrode connection types. The results presented that, according to electrical and 
sacrificial electrode costs, iron is superior to aluminum but aluminum electrode leads to high turbidity, color and COD removal efficiencies. While [36] made the treatment of sullage wastewater using electrocoagulation technique with stainless steel electrode as sacrificial anode in bipolar connection system and studied the optimum values of voltage, initial $\mathrm{pH}$ and electrolysis time were experimented, respectively. The experiments revealed that COD, BOD and SS in aqueous phase were effectively removed. The analysis of the treated water showed that the maximum COD, BOD and SS removal efficiencies were $92.71 \%$, $88.76 \%$ and $93.1 \%$, respectively at optimum conditions. [37] successfully removed heavy metal ion of cadmium $(\mathrm{Cd})$, copper $(\mathrm{Cu})$ and nickel $(\mathrm{Ni})$ from a simulated wastewater by electrocoagulation (EC) method. The experimental results indicated that the highest $\mathrm{Cd}, \mathrm{Ni}, \mathrm{Cu}$ removal were 99.78\%, 99.98\%, $98.90 \%$. [38] successfully removed of $98 \%$ of chemical oxygen demand (COD) from distillery effluent by electrocoagulation is becoming increasingly important from environmental and aesthetic point of view. Effluent from distilleries contains certain recalcitrant compounds. [39] reported a research on the removal of Reactive Red 120 in synthesized wastewater through electrocoagulation using solar energy for the purpose of improving economic efficiency of the process. Cost analysis was also performed for the treatment process. Further, the obtained optimum conditions were applied to the treatment of six samples of real textile effluent. Electrocoagulation was satisfactory in only four of the cases. Lastly, efficiency of treating the real samples was evaluated by subjecting the experimental electrodes to the SEM technique removed the phosphate from wastewater by electrocoagulation using aluminum electrodes Additional, the optimum conditions was investigated. The main objectives was determined the maximum removal efficiency of phosphate from synthetic wastewater in batch EC process. [40] investigated experimentally the removal of COD and oil from dairy wastewater using direct current (DC) electrocoagulation (EC). In the EC of dairy wastewater, the effects of initial $\mathrm{pH}$, electrolysis time, initial concentration of COD, and current intensity were examined. The COD in the aqueous phase were effectively removed when aluminum plates were used as sacrificial electrodes. The optimum operating range for each operating variable was experimentally determined. The batch experimental results revealed that COD in aqueous phase was effectively removed. The overall COD removal efficiencies extended $87 \%$ and energy consumption was $112.9 \mathrm{kWh} / \mathrm{kg}$. [41] investigated experimentally the removal of dye reactive orange 16 (RO16) by electrocoagulation using iron electrode was conducted in a batch reactor. The effect of operating parameters such as current density, initial concentration of dye, $\mathrm{pH}$ and contact time was studied and the electrical energy consumption was calculated. The maximum efficiency of hardness removal was $99.27 \%$. Also COD removal efficiency is increased to $66 \%$. Results show, electrocoagulation process by iron electrode is an effective method for reactive dye removal from colored wastewater. [42] was performed the removal of waste red mud slurry (RMW) from the 
aluminium industry. The removal efficiencies of $\mathrm{V}, \mathrm{Si}, \mathrm{Al}, \mathrm{As}$, Mo and $\mathrm{Ga}$ present in the wastewater at the optimum operating conditions $\mathrm{pH}$, current density and operating time as $97.68 \%, 82.65 \%, 98.22 \%, 99.44 \%, 99.69 \%$ and $99.95 \%$ in the EC process, respectively. The sludge produced after the EC process was characterized with scanning electron microscope. The amount of sludge and operating cost at the optimum operating conditions were calculated as $2.138 \mathrm{~kg} / \mathrm{m}^{3}$ and $0.813 € / \mathrm{m}$. [43] conducted electrocoagulation, electrooxidation and advanced electrochemical oxidation using the electro-Fenton process for removal of indigo carmine dye from aqueous solutions and dye house effluent. The electrocoagulation process was performed by sacrificial iron electrodes, the indirect electrooxidation process by dimensionally stable $\mathrm{Ti} / \mathrm{Pt}$ and graphite electrodes in $\mathrm{NaCl}$ electrolyte solution, and the electro-Fenton process by iron electrodes and added amounts of $\mathrm{H}_{2} \mathrm{O}_{2}$. All electrochemical experiments are conducted in the same electrochemical cell with the same apparent electrode surface and interelectrode distance, most efficient and economical process operated at very low current densities of 0.33 and $0.66 \mathrm{~mA} \cdot \mathrm{cm}^{-2}$ and consuming only $4.75 \times 10^{-3}$ and $5.23 \times$ $10^{-3} \mathrm{kWh} \cdot \mathrm{m}^{-3}$ of treated solution respectively. The electrocoagulation treatment with iron electrodes and the electrooxidation process with $\mathrm{Ti} / \mathrm{Pt}$ electrodes conducted at applied current densities of $5 \mathrm{~mA} \cdot \mathrm{cm}^{-2}$ consumed 0.511 and 0.825 $\mathrm{kWh} \cdot \mathrm{m}^{-3}$ of treated solution respectively. The proposed procedure is a safe, economical and efficient method for removal of indigo carmine dye from aqueous solutions and dye house effluent. [44] studied the removal efficiency of phenolic compounds by electrocoagulation process, as well as to compare the specific energy consumption (SEC) of these processes under different experimental conditions. Electrocoagulation was carried out on two different samples of water: model water of mimosa tannin and olive mill wastewater (OMW). Low carbon steel electrodes were used in the experiments. It was found that electrocoagulation treatment of effluents containing phenolic compounds involves complex formation between ferrous/ferric and phenolic compounds present in treated effluent, which has significant impact on the efficiency of the process. [45] used iron, aluminum and stainless steel electrodes to treat the textile industry wastewater in batch reactor by electrocoagulation method. The result indicates that electrocoagulation is very efficient and was able to achieve color removal (99.46\%) and COD removal (90.12\%) in the presence of iron electrode. The COD and Color removal by aluminum and stainless steel electrodes were achieved at high voltages. The energy consumption was low in case of iron electrode when compared to aluminum and stainless steel electrode for the maximum COD removal. The effluent wastewater was clear but involves post treatment to meet direct discharge standards. [46] [47] reviewed that Electrocoagulation for treating industrial effluent due to its flexibility and environmental compatibility. This technique uses direct current source between metal electrodes immersed in the effluent, which causes the dissolution of electrode plates into the effluent. The metal ions, at an appropriate $\mathrm{pH}$, can form wide range of coa- 
gulated species and metal hydroxides that destabilize and aggregate particles or precipitate and adsorb the dissolved contaminants. Therefore, the objective of the present manuscript is to review the potential of electrocoagulation for the treatment of industrial effluents, mainly removal of dyes from textile effluent. [48] studied the removal of brilliant green dye from aqueous solutions in a batch stirred electrocoagulation (EC) reactor using iron electrodes. The experimental results showed that $99.59 \%$ dye removal was observed for initial dye concentration of $100 \mathrm{mg} / \mathrm{L}$ with current density of $41.7 \mathrm{~A} / \mathrm{m}^{2}$, initial $\mathrm{pH}$ of 4.0 at the end of 30 min of operation. It was observed that, an increase in current density, time of operation and decrease in inter electrode distance improved the dye removal efficiency. Optimum $\mathrm{pH}$ for highest dye removal was 4.0 - 10.0. It was also observed that increase in salt $(\mathrm{NaCl})$ concentration in the solution reduces the specific electrical energy consumption (SEE) [49] reviewed the mechanism, affecting factors, process, and application of the electrocoagulation process. The electrocoagulation (EC) process is an electrochemical revenues of presenting coagulants and removing suspended solids, colloidal material, and metals, as well as other dissolved solids from water and wastewaters. The EC process has been successfully employed in removing pollutants, pesticides, and radionuclides. This process also removes harmful Microorganisms. More often during EC operation, direct currents applied and electrode, plates are sacrificed (dissolved into solution). The dissolution causes an increased metal concentration in the solution that finally precipitates as oxide precipitates. [50] remarkable removal of $100 \%$ of phenol from oil refinery waste effluent with lower energy consumption by using electrocoagulation technology using an electrochemical reactor with a fixed bed anode made of randomly oriented $\mathrm{Al}$ raschig rings packed in a perforated plastic basket located above the horizontal cathode. Removals of Methylene Blue dye by using an electrocoagulation process have been investigated by [51], the optimum electrolysis time, current density, concentration of the electrolyte $(\mathrm{NaOH})$ were established. The utilization of an electromagnetic field enhanced the dye removal and power consumption due to the induced motion of paramagnetic ions inside the solution. [52] effectively treated hospital wastewater .The percentage removal of Total dissolved solids; Suspended solids are $96.98 \%$ and $91.89 \%$ respectively. hospital wastewater contain solids, BOD, COD, phenols, radioactive isotopes, pathogens such as bacteria, viruses, blood, body fluid, sweat, contaminated organs, disinfectant, pharmaceuticals as well as hazardous chemicals can be effectively removed by Electrocoagulation method. [53] conducted to investigate the applicability of the electrocoagulation technique for the treatment of domestic wastewater. Iron electrodes are used and the sample is made up to run at different intervals of time, showed that only current (C) and treatment time ( $t$ ) have correlation with each other. It observed that the batch which is operated at $0.25 \mathrm{~A}$ for 20 minutes has maximum removal efficiency of Chemical Oxygen Demand, Total Dissolved Solids, pH, Color, chlorides etc. [54] treated of sewage water by electrocoagulation using stainless steel, 
iron and aluminum electrodes, the optimum condition for this treatment is detected. The optimum treatment condition reduced COD by $98.07 \%$, BOD by 98.07\%. [55] treated paint manufacturing wastewater (PMW) by electrocoagulation (EC) process. Effects of operating parameters for the EC process such as electrode type ( $\mathrm{Al}$ or $\mathrm{Fe})$, initial $\mathrm{pH}$, current and operating time were examined for optimum operating conditions. The highest removal efficiencies for COD and TOC in PMW were obtained with $93 \%$ and $88 \%$ for Fe and $94 \%$ and $89 \%$ for $\mathrm{Al}$ electrodes at the optimum conditions Costs for removal were calculated for Fe and $\mathrm{Al}$ electrodes as $0.187 € / \mathrm{m}^{3}$ and $0.129 € / \mathrm{m}^{3}$. By comparing electrode's result $\mathrm{Al}$ electrode was better than that of $\mathrm{Fe}$ electrode in terms of removal efficiency and operating cost. [56] employed electrocoagulation (EC) for removals of color, chemical oxygen demand (COD) and total organic carbon (TOC) from baker's yeast effluents (BYEs) in a batch EC reactor using aluminum electrodes. The maximum color, COD and TOC were $88 \%, 48 \%$ and $49 \%$ and operating costs were $0.418 € / \mathrm{m}^{3}$. [57] treated of marble wastewater by electrocoagulation using Aluminium and iron electrodes were investigated. The sample used was from the marble-processing plant. The optimum values of initial $\mathrm{pH}$, current density and electrolysis time was carried out using Aluminium electrode, the removal efficiencies obtained for turbidity, suspended solids, chemical oxygen demand and total solids were $98.5 \%, 99.2 \%, 55.2 \%$ and $92.4 \%$, respectively and electrode energy consumptions were $0.143 \mathrm{kWh} / \mathrm{kg}$, iron electrode, the optimum removal efficiencies for turbidity, suspended solids, chemical oxygen demand and total solids were determined as $94.3 \%, 99.1 \%, 54.2 \%$, and $96.1 \%$, respectively. Energy and electrode consumptions were $0.0571 \mathrm{kWh} / \mathrm{kg}$. [58] treated of tannery effluent to reduce chromium and COD The result indicated that $86 \%$ COD removal and $1.2 \mathrm{kWh} \cdot \mathrm{m}^{-3}$ energy consumption, 0 turbidity, $91 \%$ color abatement, 0 ppm chromium. [59] conclusively shown that the feasibility and utility of the difference between using Electrocoagulation (EC) and chemical coagulation (CC) in EC the coagulant is added by electrolytic oxidation of an appropriate anode material, while in CC dissolution of a chemical coagulant is used. These different methods in fact induce different chemical environments, which should impact coagulation/flocculation mechanisms and subsequent floc, formation. Hence, the process implications when choosing which to apply should be significant. This study elucidates differences in coagulation/flocculation mechanisms in EC versus CC and their subsequent effect on floc growth kinetics and structural evolution. A buffered kaolin suspension served as a representative solution that underwent EC and CC by applying aluminum via additive dosing regime in batch mode. In EC an aluminum anode generated the active species while in CC, commercial alum was used. Aluminum equivalent doses were applied, at initial $\mathrm{pH}$ values of 5, 6.5 and 8 , while samples were taken over pre-determined time intervals, and analyzed for $\mathrm{pH}$, particle size distribution, $\zeta$ potential, and structural properties. EC generated fragile flocs, compared to CC, over a wider $\mathrm{pH}$ range, at a substantially higher growth rate, that were prone to 
restructuring and compaction. The results suggest that the flocculation mechanism governing EC in sweep flocculent conditions is of Diffusion Limited Cluster Aggregation (DCLA) nature; versus a Reaction Limited Cluster Aggregation (RLCA) type. [60] used Electrocoagulation technology for purifying firefighting water containing fluorinated surfactants. Electrocoagulation with aluminum electrodes followed by filtration removed turbidity from pilot firefighting water. Fluorinated surfactant removal was $71 \%-77 \%$ and was not considerably increased by higher charge loading. Flocculent separation in bulk solution was completed by filtration. [61] studied the efficiency of electrocoagulation treatment process using aluminum electrodes to treat synthetic wastewater containing Reactive Red 198. The effects of parameters such as voltage, time of reaction, electrode connection mode, initial dye concentration, electrolyte concentration, and inter electrode distance on dye removal efficiency were investigated. In addition, electrical energy consumption, electrode consumption, and operating cost at optimum condition have been investigated. The results showed that dye and chemical oxygen demand removals were $98.6 \%$ and $84 \%$, respectively. Electrode consumption, energy consumption and operating cost were $0.052 \mathrm{~kg} / \mathrm{m}^{3}$, $1.303 \mathrm{kWh} / \mathrm{m}^{3}$ and $0.256 \mathrm{US} \$ / \mathrm{m}^{3}$, respectively. It can be concluded that electrocoagulation process by aluminum electrode is very efficient and clean process for reactive dye removal from colored wastewater. [62] used electrocoagulation (EC) technology to treat wastewater from landfill leachate, characterized by COD, high concentration of nitrogen and dark color. The findings, the experimental result specifies current density, the inter-electrode distance and the stirring speed. The removal efficiencies of COD, total nitrogen, color and turbidity were respectively $70 \%, 24 \%, 56 \%$, and $60 \%$ with $\mathrm{Al}$ electrodes and $68 \%, 15 \%, 28 \%$, and $16 \%$ with Fe electrodes. Electrical energy consumption and operating cost with $\mathrm{Al}$ electrodes were $0.022(\mathrm{kWh} / \mathrm{L}), 0.54\left(\mathrm{US} \$ / \mathrm{m}^{3}\right.$ leachate treated), respectively, and $0.019(\mathrm{kWh} / \mathrm{L}), 0.47\left(\mathrm{US} \$ / \mathrm{m}^{3}\right)$ with Fe electrodes. [63] used electrocoagulation system to remove As (III) and $\left.\mathrm{F}^{-}\right)$ions from water simultaneously. Dimensionally stable anodes (DSA), Fe electrodes, and $\mathrm{Al}$ electrodes were combined into an electrochemical system; it is observed that Removal efficiency of As (III) increases with the increase of solution $\mathrm{pH}$. [64] investigated the removal of chemical oxygen demand (COD) and turbidity from cardboard paper mill effluents using aluminum and iron electrodes followed by adsorption of treated wastewater on granular activated carbon (GAC). The maximum removal efficiencies of $\mathrm{COD}$ and turbidity under optimal operating conditions for $\mathrm{Al}$ and $\mathrm{Fe}$ electrode respectively, were $75.37 \%$ and $99.93 \%$, and $78.76 \%$ and $99.92 \%$ for Fe electrode, respectively. [65] inspected the decolorization up to $98 \%$, comparison to CC (limited to 53\%) of a synthetic textile wastewater containing Orange II using electrocoagulation (EC). Aluminum and iron electrodes were used. A comparison with chemical coagulation (CC) using the same amount of metal cations as in EC was also carried out. Experimental results showed that EC maximized decolorization (up to 98\%) in comparison to CC (limited to 53\%). For EC, iron elec- 
trodes exhibited the highest decolorization yield and diminished with energy requirements [66] also Performances a study of electrocoagulation process with aluminum electrodes in the treatment of $\mathrm{Cu}^{2+}, \mathrm{Zn}^{2+}$ and $\mathrm{Mn}^{2+}$ containing aqueous solutions from synthetic wastewater showed that type of anion in solutions has a substantial effect on the metal removal. Total removals of copper and zinc reached almost $100 \%$ after $5 \mathrm{~min}$, the Mn removals were $85 \%$ and $80 \%$ in the presence of sulfate and chloride anions, respectively. [67] described an electrocoagulation process for treating laundry waste-water using aluminum plates, electrical current and $\mathrm{pH}$ of the influent is a very important effects of the treatment of laundry waste-water In addition, kinetic analysis indicates that the adsorption system obeys a second-order kinetic model. It is concluded that, compared with other treatment processes, electrocoagulation is more effective in treating laundry waste-water under appropriate conditions and [68] was investigated the influence of current density, $\mathrm{pH}$ and stirring speed in the treatment of poultry slaughterhouse wastewater (PSW) using electrocoagulation process with aluminum electrodes. The best removal efficiency has been obtained $85 \%$, 98\% COD, turbidity respectively Electrical conductivity of investigated wastewater was nearly $2860 \mu \mathrm{S} / \mathrm{cm}$, which caused energy consumption to be relatively lower.

\section{Conclusion}

This research has identified a review of efficaciously electrocoagulation application, for the subtraction of precise problematic as toxicity and huge loss quantities of water that unconcerned effectively by Conventional treatment methods. However, this paper has effectively reasoned that the EC technique is alternative method for treatment wastewater. A number of studies using experimental setup in many applications of this promising technology have done better reactors design. From the above literature it can be established that the electrocoagulation is the effective method for the treatment countless wastewater and elimination solids, color, turbidity, BOD and COD. The various rewards for this promising technology are low operation and maintenance cost, high efficiency, time saving, lower sludge production without any addition of chemicals. Maybe this simple reactor in the near future will be in most various factories and water treatment company.

\section{Conflicts of Interest}

The author declares no conflicts of interest regarding the publication of this paper.

\section{References}

[1] Kara, S. (2013) Treatment of Transport Container Washing Wastewater by Electrocoagulation. Environmental Progress \& Sustainable Energy, 32, 249-256. https://doi.org/10.1002/ep.11616

[2] Khaled, B., Wided, B., Bechir, H., Elimame, E., Mouna, L. and Zied, T. (2015) In- 
vestigation of Electrocoagulation Reactor Design Parameters Effect on the Removal of Cadmium from Synthetic and Phosphate Industrial Wastewater. Arabian Journal of Chemistry, 2.

[3] Lopez, V.R., Saez, C., Cañizares, P. and Rodrigo, M. (2012) Electrocoagulation of the Effluents from Surfactant-Aided Soil-Remediation Processes. Separation and Purification Technology, 98, 88-93. https://doi.org/10.1016/j.seppur.2012.07.017

[4] Mansour, S. and Hasieb, H. (2012) Removal of Ni (II) and Co (II) Mixtures from Synthetic Drinking Water by Electrocoagulation Technique Using Alternating Current. International Journal of Chemical Technology, 4, 31-44.

[5] Dehghani, M., Seresht, S. and Hashemi, H. (2014) Treatment of Hospital Wastewater by Ectrocoagulationusing Aluminum and Iron Electrodes. International Journal of Environmental Health Engineering, 3, 15. https://doi.org/10.4103/2277-9183.132687

[6] Dehghani, M. and Hashemi, H. (2014) Treatment of Hospital Waste Water by Electrocoagulation Using Aluminium and Iron Electrode.

[7] Almazán, R. Caballero, F. Cruz, V., Díaz, M., Rivero, E. and Gonzalez, I. (2012) Scale-Up of Rotating Cylinder Electrode Electrochemical Reactor for $\mathrm{Cu}(\mathrm{II})$ Recovery: Experimental and Simulation Study in Turbulence Regimen. Electrochimica Acta, 77, 262-271. https://doi.org/10.1016/j.electacta.2012.06.003

[8] Valente, G., Mendonca, R. and Pereira, J. (2015) The Efficiency of Electrocoagulation Using Aluminum Electrodes in Treating Wastewater from a Dairy Industry. Ciência Rural, 45, 1713-1719. https://doi.org/10.1590/0103-8478cr20141172

[9] Valero, D., García, V., Expósito, E., Aldaz, A. and Montiel, V. (2015) Application of Electrodialysis for the Treatment of Almond Industry Wastewater. Journal of Membrane Science, 476, 580-589. https://doi.org/10.1016/j.memsci.2014.11.007

[10] Silva, D., Mercon, F., Cerqueira, A., Ximango, P., Costa, D. and Marques, M. (2015) Evaluation of Electrocoagulation as Prertreatment of Oil Emulsions Followed by Reverse Osmosis. Journal of Water Process Engineering, 8, 126-135. https://doi.org/10.1016/j.jwpe.2015.09.009

[11] Jame, S. (2012) Electrochemical Treatment of Synthetic Wastewater Containing Textile Dyes. Lamar University, Texas, USA.

[12] Naje, A.S. and Abbas, S.A. (2013) Electrocoagulation Technology in Wastewater Treatment: A Review of Methods and Applications. Civil and Environmental Research, 3, 29-42.

[13] Mahammedrafi, P. (2018) An Experimental Study of Electrocoagulation Process Applied for Influence of Fluoride Ions on Hardness Removal. International Journal of Engineering Research and Application, 8, 33-38.

[14] Warren, R., Lisveth, V., Flores, P., José, L., Guerrero, G., Josué, T., Rea-Marcos, L.M., María, E., Santos, R. and Yuli, P. (Benefits of Electrocoagulation in Treatment of Wastewater) (2018) Removal of Fe and Mn Metals, Oil and Grease and COD. International Journal of Applied Engineering Research, 13, 6450-6462.

[15] Naraghi, B., Baneshi, M.M., Amiri, R., Dorost, A. and Biglari, H. (2018) Removal of Reactive Black 5 Dye from Aqueous Solutions by Coupled Electrocoagulation and Bio-Adsorbent Process. Electronic Physician, 10, 7086-7094.

https://doi.org/10.19082/7086

[16] Thakur, S. and Chauhan, M.S. (2018) Treatment of Dye Wastewater from Textile Industry by Electrocoagulation and Fenton Oxidation: A Review. In: Singh, V., Yadav, S. and Yadava, R., Eds., Water Quality Management. Water Science and Tech- 
nology Library, Vol. 79, Springer, Singapore, 117-129.

https://doi.org/10.1007/978-981-10-5795-3_11

[17] Singh, H. and Mishra, B.K. (2017) Assessment of Kinetics Behavior of Electrocoagulation Process for the Removal of Suspended Solids and Metals from Synthetic Water. Environmental Engineering Research, 22, 141-148.

[18] Majumder, S. and Rida, U. (2017) Removal of COD from Textile Mill Wastewater by Electro-Coagulation Process Using SS/Al as Composite Hydrogel Electrode. International Journal of Innovative Research in Science, Engineering and Technology, 6, $17242-17250$.

[19] Zazouli, M.A., Ahmadi, M. and Charati, J.Y. (2017) Pretreatment of Paper Recycling Plant Wastewater by Electrocoagulation Using Aluminum and Iron Electrodes. Journal of Materials and Environmental Sciences, 8, 2140-2146.

[20] Li, R., Wang, B., Owete, O., Dertien, J., Lin, C., Ahmad, H. and Chen, G. (2017) Landfill Leachate Treatment by Electrocoagulation and Fiber Filtration. Water Environmental Research, 89, 2015-2020.

[21] Song, P.P., Yang, Z.H., Zeng, G.M., Yang, X., et al. (2017) Electrocoagulation Treatment of Arsenic in Wastewaters. Chemical Engineering Journal, 81, 707-725.

[22] Bejjany, B., Lekhlif, B., Eddaqaq, F., Dani, A., Mellouk, H. and Khalid, D. (2017) Treatment of the Surface Water by Electrocoagulation-Electroflotation Process in Internal Loop Airlift Reactor Conductivity Effect on Turbidity Removal and Energy Consumption. Journal of Materials and Environmental Science, 8, 2757-2768.

[23] Maghanga, J., Segor, K., Irina, J. and Tole, M. (2017) Effect of Process Parameters on the Electro Coagulation of Azo-Dye Wastewater in a Kenyan Textile Factory. IOSR Journal of Applied Chemistry, 10, 1-7.

[24] Alimohammadi, M., Askari, M., Dehghani, M., Dalvand, A. Saeedi, R., Yetilmezsoy, K., Heibati, B. and McKay, G. (2017) Elimination of Natural Organic Matter by Electrocoagulation Using Bipolar and Monopolar Arrangements of Iron and Aluminum Electrodes. International Journal of Environmental Science and Technology, 14, 2125-2134. https://doi.org/10.1007/s13762-017-1402-3

[25] Vidal, J., Espinoza, C., Contreras, N. and Salazar, R. (2017) Elimination of Industrial Textile Dye by Electrocoagulation Using Iron Electrodes. Journal of the Chilean Chemical Society, 62, 3519-3524.

[26] Sajjadi, S.A., Pakfetrat, A. and Irani, M. (2017) Removal of Remazol Black B Dye by Electrocoagulation Process Coupled with Bentonite as an Aid Coagulant and Natural Adsorbent. Iranian Journal of Health, Safety \& Environment, 5, 1058-1065.

[27] Osman, A.T., Elamin, M.R. and Almalki, M.H. (2017) Treatment of Tannery Wastewater with Nano-Electrocoagulation Process. Journal of Environmental \& Analytical Toxicology, 7, 508.

[28] Nwabanne, J.T. and Obi, C.C. (2017) Abattoir Wastewater Treatment by Electrocoagulation Using Iron Electrodes. Der Chemica Sinica, 8, 254-260.

[29] Ghalwa, N.M., Musabeh, A.Z. and Farhat, N.B. (2017) Performance Efficiency of Electrocoagulation Adsorption Process of Oxyfluorfen Herbicide from Aqueous Solutions Using Different Anodes. Journal of Environmental and Analytical Toxicology, 7, 448.

[30] Garg, U.K. and Sharma, C. (2016) Electrocoagulation: Promising Technology for Removal of Fluoride from Drinking Water-A Review. Biological Forum, 8, 248-254.

[31] Eyvaz, M. (2016) Treatment of Brewery Wastewater with Electrocoagulation: Im- 
proving the Process Performance by Using Alternating Pulse Current. International Journal of Electrochemical Science, 11, 4988-5008. https://doi.org/10.20964/2016.06.11

[32] Vidal, J., Villegas, L., Peralta-Hernández, J.M. and González, R.S. (2016) Removal of Acid Black 194 Dye from Water by Electrocoagulation with Aluminum Anode. Journal of Environmental Science and Health, Part A, 51, 289-296. https://doi.org/10.1080/10934529.2015.1109385

[33] Singh, A., Srivastava, A., Tripathi, A. and Dutt, N.N. (2016) Optimization of Brilliant Green Dye Removal Efficiency by Electrocoagulation Using Response Surface Methodology. World Journal of Environmental Engineering, 4, 23-29.

[34] Gonçalves, M.V.B., De Oliveira, S.C., Abreu, B.M.P.N., Guerra, E.M. and Cestarolli, D.T. (2016) Electrocoagulation/Electroflotation Process Applied to Decolourization of a Solution Containing the Dye Yellow Sirius K-CF. International Journal of Electrochemical Science, 11, 7576-7583. https://doi.org/10.20964/2016.09.42

[35] Zainab, A.H. and Noor, J. (2016) Removal of Reactive Black Wastewater by Electrocoagulation Dye from Synthetic Technique. Journal of Engineering and Sustainable Development, 20, 40-54.

[36] Santhosh, P., Revathi, D. and Saravanan, K. (2015) Treatment of Sullage Wastewater by Electrocoagulation Using Stainless Steel Electrodes. International Journal of Chemical Science, 13, 1173-1186.

[37] Un, U.T. and Ocal, S.E. (2015) Removal of Heavy Metals (Cd, Cu, Ni) by Electrocoagulation. International Journal of Environmental Science and Development, 6, 425-429. https://doi.org/10.7763/IJESD.2015.V6.630

[38] Khandegar, V. and Saroha, A. (2015) Electrochemical Treatment of Distillery Spent Wash Using Aluminum and Iron Electrodes. Chinese Journal of Chemical Engineering, 20, 439-443. https://doi.org/10.1016/S1004-9541(11)60204-8

[39] Pirkarami, A. and Olya, M.E. (2014) Removal of Dye from Industrial Wastewater with an Emphasis on Improving Economic Efficiency and Degradation Mechanism. Journal of Saudi Chemical Society, 21, S179-S186. https://doi.org/10.1016/j.jscs.2013.12.008

[40] Sharma, D. (2014) Treatment of Dairy Waste Water by Electrocoagulation Using Aluminum Electrodes and Settling, Filtration Studies. International Journal of ChemTech Research, 6, 591-599.

[41] Alizadeh, M., Mahvi, A. and Mansoorian, H. (2014) The Survey of Electrocoagulation Process for Removal Dye Reactive Orange 16 from Aqueous Solutions Using Sacrificial Iron Electrodes. Iranian Journal of Health, Safety and Environment, 1, $1-8$.

[42] Kobia, M., Oncel, E., Demrabase, S., Akyole, A. and Ince, M. (2014) The Application of Electrocoagulation Process for Treatment of the Red Mud Dam Wastewater from Bayer's Process. Journal of Environmental Chemical Engineering, 2, 2211-2220. https://doi.org/10.1016/j.jece.2014.09.008

[43] Stergiopoulos, D., Dermentzis, K., Giannakoudakis, P. and Sotiropoulos, S. (2014) Electrochemical Decolorization and Removal of Indigo Carmine Textile Dye from Wastewater. Global NEST Journal, 16, 499-506. https://doi.org/10.30955/gnj.001330

[44] Rokovic, M.K., Čubrić, M. and Wittine, O. (2014) Phenolic Compounds Removal from Mimosa Tannin Model Water and Olive Mill Wastewater by Energy-Efficient Electrocoagulation Process. Journal of Electrochemical Science and Engineering, 4, 215-225. 
[45] Akanksha, Roopashree, G.B. and Lokesh, K.S. (2014) Comparative Study of Electrode Material (Iron, Aluminium and Stainless Steel) for Treatment of Textile Industry Wastewater. International Journal of Environmental Sciences, 4, 519-531.

[46] Barrera-Díaz, D., Lugo-Lugo, V. and Bilyeu, B. (2012) A Review of Chemical, Electrochemical and Biological Methods for Aqueous $\mathrm{Cr}$ (VI) Reduction. Journal of Hazardous Materials, 223-224, 1-12. https://doi.org/10.1016/j.jhazmat.2012.04.054

[47] Khandegar, V. and Saroha, A. (2013) Electrocoagulation for the Treatment of Textile Industry Effluent-A Review. Journal of Environmental Management, 128, 949-963. https://doi.org/10.1016/j.jenvman.2013.06.043

[48] Nandi, B. and Patel, S. (2013) Effects of Operational Parameters on the Removal of Brilliant Green Dye from Aqueous Solutions by Electrocoagulation. Arabian Journal of Chemistry, 10, S2961-S2968. https://doi.org/10.1016/j.arabjc.2013.11.032

[49] Sahu, O., Mazumdar, B. and Chaudhari, P.K. (2014) Treatment of Wastewater by Electrocoagulation. Environmental Science and Pollution Research, 21, 2397-2413. https://doi.org/10.1007/s11356-013-2208-6

[50] El-Ashtoukhy, E., El-Taweel, Y., Abdelwahab, O. and Nassef, E. (2013) Treatment of Petrochemical Wastewater Containing Phenolic Compounds by Electrocoagulation Using a Fixed Bed Electrochemical Reactor. International Journal of Electrochemical Science, 8, 1534-1550.

[51] Mahmoud, M.S., Farah, J.Y. and Farrag, T.E. (2013) Enhanced Removal of Methylene Blue by Electrocoagulation Using Iron Electrodes. Egyptian Journal of Petroleum, 22, 211-216. https://doi.org/10.1016/j.ejpe.2012.09.013

[52] Mahajan, R., Khandegar, V. and Saroha, A. (2013) Treatment of Hospital Operation Theatre Effluent by Electrocoagulation. International Journal of Chemical and Environmental Engineering, 4, 104-107.

[53] Sarala, C. (2012) Omestic Wastewater Treatment by Electrocoagulation with Fe-Fe Electrodes. International Journal of Engineering Trends and Technology, 3, 530-533.

[54] Nasrullah, M., Singh, L. and Wahida, A. (2012) Treatment of Sewage by Electrocoagulation and the Effect of High Current Density. International Journal of Energy and Environmental Engineering, 1, 27-31.

[55] Akyol, A. (2012) Treatment of Paint Manufacturing Wastewater by Electrocoagulation. Desalination, 285, 91-99. https://doi.org/10.1016/j.desal.2011.09.039

[56] Gengec, E., Kobya, M., Demirbas, E., Akyol, A. and Oktor, K. (2012) Optimization of Baker's Yeast Wastewater Using Response Surface Methodology by Electrocoagulation. Desalination, 286, 200-209. https://doi.org/10.1016/j.desal.2011.11.023

[57] Ozyonar, F. and Karagozoglu, B. (2012) Systematic Assessment of Electrocoagulation for the Treatment of Marble Processing Wastewater. International Journal of Environmental Science and Technology, 9, 637-646. https://doi.org/10.1007/s13762-012-0093-Z

[58] Zongo, I., Merzouk, B., Palm, K., Wethe, J., Hama Maiga, A., et al. (2012) Study of an Electrocoagulation (EC) Unit for the Treatment of Industrial Effluent of Ouagadougou, Burkina Faso. Advances in Applied Science Research, 3, 572-582.

[59] Harif, T., Khai, M. and Adin, A. (2012) Electrocoagulation versus Chemical Coagulation Coagulation/Flocculation Mechanisms and Resulting Floc Characteristics. Water Research, 46, 3177-3188. https://doi.org/10.1016/j.watres.2012.03.034

[60] Baudequin, C., Couallier, E., Rakib, M., Deguerry, I., Severac, R. and Pabon, M. (2011) Purification of Firefighting Water Containing a Fluorinated Surfactant by Reverse Osmosis Coupled to Electrocoagulation-Filtration. Separation and Purifica- 
tion Technology, 76, 275-282. https://doi.org/10.1016/j.seppur.2010.10.016

[61] Dalvand, A., Gholami, M., Joneidi, A. and Mahmoodi, N. (2011) Dye Removal, Energy Consumption and Operating Cost of Electrocoagulation of Textile Wastewater as a Clean Process. CLEAN-Soil, Air, Water, 39, 665-672.

https://doi.org/10.1002/clen.201000233

[62] Bouhezila, F., Hariti, M., Lounici, H. and Mameri, N. (2011) Treatment of the OUED SMAR Town Landfill Leachate by an Electrochemical Reactor. Desalination, 280, 347-353. https://doi.org/10.1016/j.desal.2011.07.032

[63] Zhao, X., Zhang, B., Liu, H. and Qu, J. (2011) Simultaneous Removal of Arsenite and Fluoride via an Integrated Electro-Oxidation and Electrocoagulation Process. Chemosphere, 83, 726-729. https://doi.org/10.1016/j.chemosphere.2011.01.055

[64] Bellebia, S., Kacha, S., Bouyakoub, A. and Derriche, Z. (2011) Experimental Investigation of Chemical Oxygen Demand and Turbidity Removal from Cardboard Paper Mill Effluents Using Combined Electrocoagulation and Adsorption Processes. Environmental Progress \& Sustainable Energy, 31, 361-370. https://doi.org/10.1002/ep.10556

[65] Chafi, M., Gourich, B., Essadki, A., Vial, C. and Fabregat, A. (2011) Comparison of Electrocoagulation Using Iron and Aluminium Electrodes with Chemical Coagulation for the Removal of a Highly Soluble Acid Dye. Desalination, 281, 285-292. https://doi.org/10.1016/j.desal.2011.08.004

[66] Hanay, Ö. and Hasar, H. (2011) Effect of Anions on Removing $\mathrm{Cu}^{2+}, \mathrm{Mn}^{2+}$ and $\mathrm{Zn}^{2+}$ in Electrocoagulation Process Using Aluminum Electrodes. Journal of Hazardous Materials, 189, 572-576. https://doi.org/10.1016/j.jhazmat.2011.02.073

[67] Janpoor, F., Torabian, A. and Khatibikamal, V. (2011) Treatment of Laundry Waste-Water by Electrocoagulation. Journal of Chemical Technology \& Biotechnology, 86, 1113-1120. https://doi.org/10.1002/jctb.2625

[68] Bayar, S., Yıldız, Y., Yılmaz, A. and Irdemez, S. (2011) The Effect of Stirring Speed and Current Density on Removal Efficiency of Poultry Slaughterhouse Wastewater by Electrocoagulation Method. Desalination, 280, 103-107. https://doi.org/10.1016/j.desal.2011.06.061 


\section{Abbreviation}

AC, alternating current (amp); BOD, biochemical oxygen demand (mg/L); COD, chemical oxygen demand (mg/L); DC, direct current (amp); F, Faraday's constant (96, $500 \mathrm{C} / \mathrm{mol})$; ppm, parts per million; SS, suspended solids (mg/L); TDS, total dissolved solids (mg/L); TFS, total fixed solids (mg/L); TOC, total organic carbon (mg/L); TSS, total suspended solids (mg/L); TVS, total volatile solids $(\mathrm{mg} / \mathrm{L})$.

\section{Nomenclature}

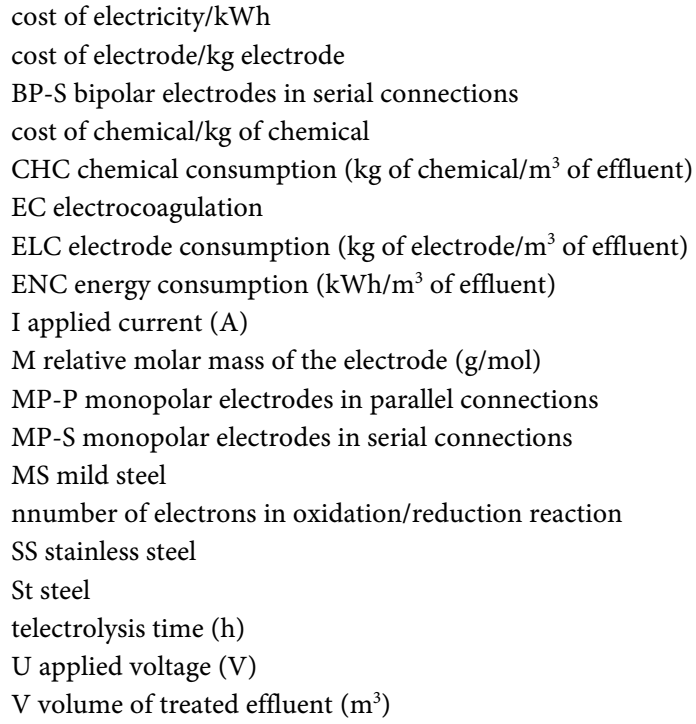

